\title{
The Inhibition of Growth of Escherichia coli Spheroplasts by Antibacterial Agents
}

\author{
By A. B. SPICER* AND D. F. SPOONER \\ Research Department, The Boots Co. Ltd, Nottingham
}

(Received I9 February I973; revised 8 August 1973 )

SUMMARY

Escherichia coli NCTC 86 organisms with impaired walls were prepared by three methods and the effect of antibacterial agents on their growth studied. The growth of penicillin spheroplasts was masked by the overgrowth of unaltered cells in the culture; the EDTA-lysozyme spheroplasts themselves were non-viable. The growth of penicillin spheroplasts was not affected by cell-wall inhibitors and ampicillin suppressed the overgrowth of unaltered cells. The sensitivity of penicillin spheroplasts and parent cells to inhibition by a range of agents was similar. EDTA treatment enhanced the susceptibility of $E$. coli NCTC 86 and other strains of Gramnegative species to several antibiotics, particularly erythromycin. Polyacetic acid chelating agents related to EDTA and some new amides derived from glycine, alanine, phenylalanine or methionine also potentiated erythromycin in vitro. Erythromycin showed some activity in protecting mice against infection by EDTAtreated E. coli NCTC 86 . The antibiotic did not protect against infection by the untreated bacteria and its activity was not greatly enhanced by simultaneous administration of EDTA or the amide derivatives.

\section{INTRODUCTION}

Since the discovery of penicillin much attention has been given to the inhibition of bacterial cell-wall synthesis, but comparatively little is known about the protection that the outer layers of bacteria afford against antibacterial agents. In general, Gram-negative bacteria are less sensitive than Gram-positive bacteria to antibiotics and synthetic antibacterial compounds and their walls are more complex. It has not been established to what extent these properties are related and a comparison of the growth-inhibitory activity of suitable compounds on Gram-negative bacteria and their spheroplasts could be informative.

Several studies of the effect of antibacterial compounds on the growth and metabolic activities of Gram-positive protoplasts have been made (Gilby \& Few, I960 $a, b$; Shockman \& Lampen, I962; Yudkin, I963; Hancock \& Fitz-James, I964; Reynolds, I966), but there are few accounts of studies with Gram-negative bacteria, possibly because protoplasts have not been unequivocally obtained from them. Razin \& Argaman(I963) used penicillin spheroplasts of Escherichia coli to compare the effect of surfactants. The effect of actinomycin D on the synthesis of protein (Haywood \& Sinsheimer, 1963; Leive, 1965a) and nucleic acid (Mach \& Tatum, 1963) by EDTA-lysozyme spheroplasts of E. coli has been recorded. Gauze, Loshkaseva \& Yu (1965) have demonstrated that oligomycin suppressed RNA synthesis in $E$. coli spheroplasts but not in the whole organism.

This paper describes the effect of a range of agents on the growth of Escherichia coli after the attempted removal or modification of the cell wall.

\footnotetext{
* Present address: Department of Science, Oxford Polytechnic, Headington, Oxford.
} 


\section{Organisms}

\section{METHODS}

Some strains of Escherichia coli, of clinical origin, designated PHL, were obtained from Dr E. R. Mitchell, Nottingham Public Health Laboratory. E. coli I202, E. coli I203, Proteus vulgaris A 479, Pseudomonas aeruginosa Io s, Shigella flexneri WB I and Staphylococcus aureus DAKIN were from The Boots Co., Ltd, Nottingham, culture collection. All other bacteria were obtained from the National Collection of Type Cultures.

\section{Media}

Nutrient broth (g/l): neopeptone (Difco Laboratories, Detroit, Michigan, U.S.A.), $15 \cdot 0$; glucose, $\mathrm{r} \cdot 0$; sodium chloride, $5 \cdot 0$; yeast extract (Difco), $3 \cdot 0 ; \mathrm{pH}_{7 \cdot 2 .}$

Nutrient agar. Nutrient broth supplemented with $15^{\circ} 0 \mathrm{~g}$ agar/l.

Spheroplast growth (SG) broth. Nutrient broth supplemented with $0.5 \mathrm{M}$-sucrose and $0.2 \%(\mathrm{w} / \mathrm{v})$ magnesium sulphate.

Semi-synthetic (SS) medium. To the basal synthetic medium of Loveless, Spoerl \& Weisman (1954) were added (g/l): glucose, 20.0; L-glutamic acid, 0.5; L-arginine, 0.I; L-histidine, 0.05 ; yeast extract, $\mathrm{I} \cdot 0 ; \mathrm{pH} 7 \cdot 0$. This enriched medium was made isotonic for Escherichia coli by the addition of $0.3 \mathrm{M}$-sucrose.

Complex $(C)$ broth (g/l): neopeptone, I0.0; beef extract ('Lab. Lemco', Oxoid) 3.0; sodium chloride, $5 \cdot 0 ; \mathrm{pH} 7 \cdot 0$. This medium was made isotonic for Escherichia coli by the addition of 0.3 M-sucrose.

Complex $(C)$ agar. C broth supplemented with $15.0 \mathrm{~g}$ agar/l.

\section{Antibiotics and antibacterial agents}

Some amides of ethylenediamine tetra-acetic acid (EDTA) of the general form:<smiles>[R]OCCNCC(=O)O[Na]</smiles>

where $\mathrm{R}$ represents an amino acid residue, were prepared in our laboratories by Dr K. J. Nichol. These compounds may be regarded as being derived from one molecule of EDTA and two molecules of one of the amino acids glycine, D- or DL-alanine, DL-phenylalanine or DL-methionine. Aqueous solutions of the compounds appeared stable; the synthesis of the compounds will be published elsewhere.

Cephalosporin PI and quinacillin were supplied by Boots; actinomycin D by Merck, Sharp and Dohme Ltd, Hoddesden, Hertfordshire; gramicidin by Lundebeck and Co., Copenhagen, Denmark; oleandomycin by Roche Products Ltd, Welwyn Garden City, Hertfordshire; sodium dodecyl sulphate by BDH Chemicals Ltd, Poole, Dorset and tetrachlorosalicylanilide by CIBA-Geigy (U.K.) Ltd, London. Ampicillin, benzylpenicillin, cephaloridine, cycloserine, bacitracin, erythromycin, lincomycin, novobiocin, vancomycin, chloramphenicol, neomycin and polymyxin B were of British Pharmacopoeial quality.

\section{Preparation of spheroplasts}

Treatment with EDTA and lysozyme. The method of Voss (1964) was followed with certain modifications. Nutrient broth $(100 \mathrm{ml})$ in a $500 \mathrm{ml}$ flask was inoculated from a $\mathrm{I} 6 \mathrm{~h}$ agar culture of Escherichia coli and shaken for $24 \mathrm{~h}$ at $37^{\circ} \mathrm{C}$. Four $\mathrm{ml}$ of the culture were centri- 
fuged at $20^{\circ} \mathrm{C}$ and the bacteria washed twice with sterile distilled water and resuspended in $2.5 \mathrm{ml}$ of water. Two $\mathrm{ml}$ of the suspension were added to $0.3 \mathrm{ml}$ EDTA solution $(0.03 \mathrm{M})$, $0.24 \mathrm{ml}$ lysozyme solution $(500 \mu \mathrm{g} / \mathrm{ml}), 0.2 \mathrm{ml}$ tris buffer $(\mathrm{I} \cdot \mathrm{O} \mathrm{M}), \mathrm{I} \cdot 2 \mathrm{ml}$ sucrose solution $(\mathrm{I} .5 \mathrm{M})$ and distilled water $(2.06 \mathrm{ml})$ and incubated at $37^{\circ} \mathrm{C}$ for $30 \mathrm{~min}$ without shaking.

Treatment with benzylpenicillin. A method similar to that of Hirokawa (1962) was used. Nutrient broth ( $100 \mathrm{ml}$ ) contained in a $500 \mathrm{ml}$ conical flask was inoculated with a loop-full of Escherichia coli NCTC 86 taken from a nutrient agar slope culture and incubated at $37^{\circ} \mathrm{C}$ with shaking for $\mathrm{I} 8 \mathrm{~h}$. The culture was then diluted fivefold with $\mathrm{SG}$ broth containing $\mathrm{I} \cdot 0 \mathrm{mg}$ benzylpenicillin $/ \mathrm{ml}$. A hundred $\mathrm{ml}$ of this suspension were shaken at $37^{\circ} \mathrm{C}$ in a $500 \mathrm{ml}$ flask for $4 \mathrm{~h}$ and then stored without shaking at $5{ }^{\circ} \mathrm{C}$ for $\mathrm{I} 6 \mathrm{~h}$. The suspension was centrifuged at I $500 \mathrm{~g}$ for $20 \mathrm{~min}$ at $20^{\circ} \mathrm{C}$ and the deposited spheroplasts resuspended in SG broth. To inactivate the penicillin, $0^{\circ} \mathrm{I} \mathrm{ml}$ of a preparation of Bacillus subtilis penicillinase was then added to $10 \mathrm{ml}$ of the suspension which was maintained at $20^{\circ} \mathrm{C}$ for $60 \mathrm{~min}$. The inactivation of benzylpenicillin in the suspension was confirmed by an agar diffusion assay using Staphylococcus aureus DAKIN as the assay organism. Finally the spheroplast suspension was centrifuged at $\mathrm{I} 500 \mathrm{~g}$ for $20 \mathrm{~min}$ at $20^{\circ} \mathrm{C}$ and resuspended in fresh $\mathrm{SG}$ broth.

\section{Treatment with EDTA}

A method similar to that described by Leive $(1965 b)$ was used. A I $6 \mathrm{~h}$ culture in nutrient broth was centrifuged at $\mathrm{I} 500 \mathrm{~g}$ for $20 \mathrm{~min}$ at $20^{\circ} \mathrm{C}$, the deposit washed twice with $0 \cdot \mathrm{I} \mathrm{M}$-tris buffer $\left(\mathrm{pH} 8{ }^{\circ}\right)$ and resuspended in fresh tris buffer. The suspension was then adjusted with tris buffer to contain approx. $2 \times 10^{9}$ bacteria $/ \mathrm{ml}$. Samples $(9 \cdot 0 \mathrm{ml})$ of this suspension were warmed to $37^{\circ} \mathrm{C}$ and $\mathrm{I} \cdot 0 \mathrm{ml}$ EDTA solution $(2 \cdot 0 \mathrm{~mm}$ in tris buffer, $\mathrm{pH} 8 \cdot 0)$ added. To a control suspension, $\mathrm{I} \cdot 0 \mathrm{ml}$ tris buffer only was added. After incubating at $37^{\circ} \mathrm{C}$ for $2 \mathrm{~min}$, the suspensions were diluted tenfold with nutrient broth to inactivate the chelating agent.

\section{Turbidimetric measurement of growth}

Suitably diluted suspensions $(0.5 \mathrm{ml})$ were inoculated into $4.5 \mathrm{ml}$ of broth prewarmed to $37{ }^{\circ} \mathrm{C}$, containing various concentrations of antibacterial drugs, in Monod tubes (Kay \& Fildes, 1950). Inoculations of successive tubes were made at $30 \mathrm{~s}$ intervals, the Monod tubes shaken (100 cycles/min of $7 \mathrm{~cm}$ amplitude) at $37^{\circ} \mathrm{C}$, and measurements of extinction, at the same $30 \mathrm{~s}$ intervals, were made periodically in a spectrophotometer (Unicam SP 600 fitted with the SP 630 test-tube holder) at $580 \mathrm{~nm}$.

\section{Osmotic-fragility test}

Two portions of spheroplast suspension were centrifuged at $1500 \mathrm{~g}$ for $20 \mathrm{~min}$ and the deposits gently resuspended in an equal volume of water or of either 0.3 or $0.5 \mathrm{M}$-sucrose. The extinctions of these suspensions were then compared. Control suspensions of Escherichia coli were similarly treated.

\section{Viable counts}

Samples of bacterial suspensions were appropriately diluted in ice-cold nutrient broth, duplicate $\mathrm{I} \cdot 0 \mathrm{ml}$ samples were withdrawn and immediately mixed with nutrient agar using the pour plate technique. Colonies were counted after $48 \mathrm{~h}$ incubation at $37^{\circ} \mathrm{C}$.

\section{Electron microscopy}

Penicillin spheroplasts were fixed and stained with buffered osmic acid according to the procedure of Voss (1964). Untreated and EDTA-treated samples of Escherichia coli were 
both fixed with buffered glutaraldehyde solution and subsequently stained with buffered osmic acid (Glauert \& Thornley, 1966).

After extensive washing with glass-distilled water the bacteria were examined with an AEI-EM6G electron microscope.

\section{Mouse-protection tests}

Groups of ten albino, $20 \mathrm{~g}$, male Schofield mice were dosed subcutaneously or orally with test-compounds. One hour later the animals were infected by the intraperitoneal injection of $3.5 \times 10^{5}$ (approx. I00 $\times$ LD 50) EDTA-treated or untreated Escherichia coli NCTC 86 organisms suspended in $0.5 \mathrm{~m}$ hog gastric mucin (Wilson Laboratories, Chicago, U.S.A). Deaths over the next 7 days were recorded and mean survival times (M.S.T.) computed by the method of Litchfield (1949).

\section{RESULTS}

\section{Penicillin spheroplasts}

Phase contrast microscopy showed that $>90 \%$ of the organisms were converted and the resulting suspensions were mainly composed of osmotically-fragile bodies. When incubated at $37^{\circ} \mathrm{C}$ in SG broth the extinction of the suspensions increased substantially and, throughout the first $3 \mathrm{~h}$ incubation, many of the spheroplasts increased in size. Over the next $2 \mathrm{~h}$, many irregular-shaped organisms were observed (Fig. I $c$ ), probably spheroplasts reverting to the normal rod-shaped form. About $5 \%$ of unaltered bacteria were present initially in the spheroplast suspensions and this proportion increased on incubation until, after $6 \mathrm{~h}$, the suspensions consisted almost entirely of rods.

The growth of preparations of spheroplasts (approx. $2 \times 10^{8} / \mathrm{ml}$ ) in SG broth, in the presence or absence of different concentrations of ampicillin, were compared. After incubation for $3 \mathrm{~h}$, spheroplast suspensions containing $5 \mu \mathrm{g}$ ampicillin $/ \mathrm{ml}$ did not show reversion forms and the proportion of rods was no higher than at the start of the incubation period. The addition of ampicillin did not significantly affect the increase of extinction during the first $2.5 \mathrm{~h}$ or the enlargement of individual spheroplasts (Fig. I $b, c$ ), but thereafter the extinction remained constant. Ampicillin $(5 \mu \mathrm{g} / \mathrm{ml})$ prevented growth of an inoculum of Escherichia coli equivalent to that present initially in spheroplast suspensions (approx. $\mathrm{I} \times 10^{7} / \mathrm{ml}$ ) and it was concluded that multiplication of unconverted cells was not responsible for the turbidimetric increase occurring during the first $2.5 \mathrm{~h}$. The increase in turbidity was abolished by the addition of $5 \mu \mathrm{g}$ chloramphenicol/ml and phase-contrast microscopy showed that this antibiotic prevented the spheroplasts from increasing in size during a $4 \mathrm{~h}$ incubation period. Thus the increase in turbidity appeared to be due to growth of the spheroplasts.

The effect of a range of chemotherapeutic agents was compared on the growth of Escherichia coli penicillin spheroplasts and control organisms. The concentration required to produce $50 \%$ inhibition of growth yield $\left(E D_{50}\right)$ after incubation for $3 \mathrm{~h}$ was determined. The cell-wall inhibitors tested, ampicillin, benzylpenicillin, cephaloridine, cycloserine and quinacillin, were virtually without effect upon the spheroplasts, although, with the exception of quinacillin, they all inhibited the normal organisms at comparatively low concentrations. Actinomycin D, bacitracin, cephalosporin PI, chloramphenicol, erythromycin, gramicidin, lincomycin, neomycin, novobiocin, oleandomycin, polymyxin B and vancomycin were not significantly different in their effects on the two forms. In contrast, both sodium dodecyl sulphate (SDS) and tetrachlorosalicylanilide (TCS) were significantly $(P \leqslant 0.05)$ more effective against penicillin spheroplasts than against normal organisms. 


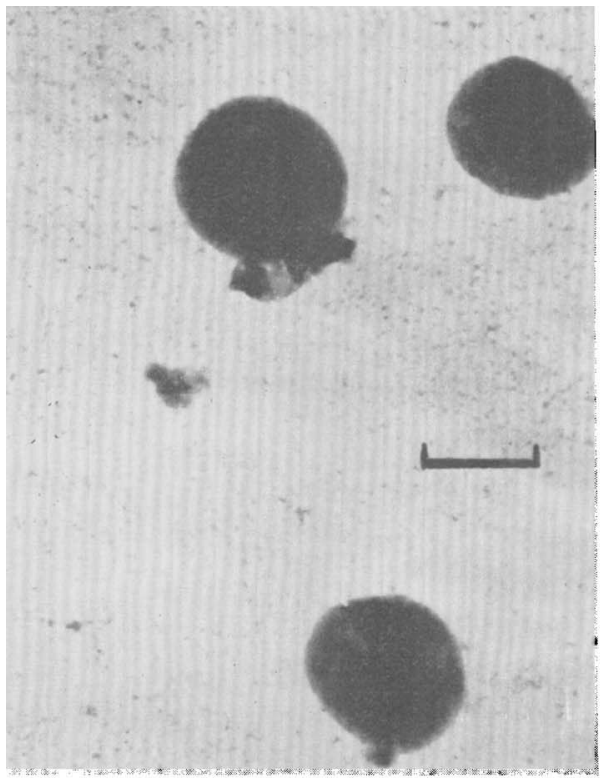

(a)

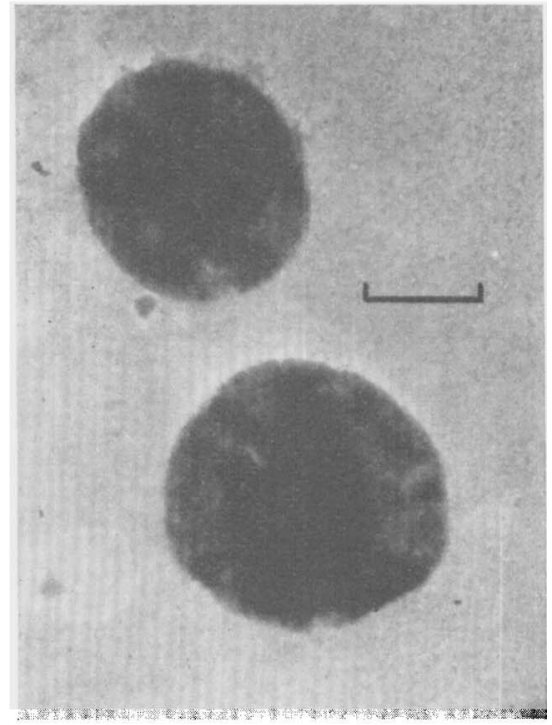

(b)

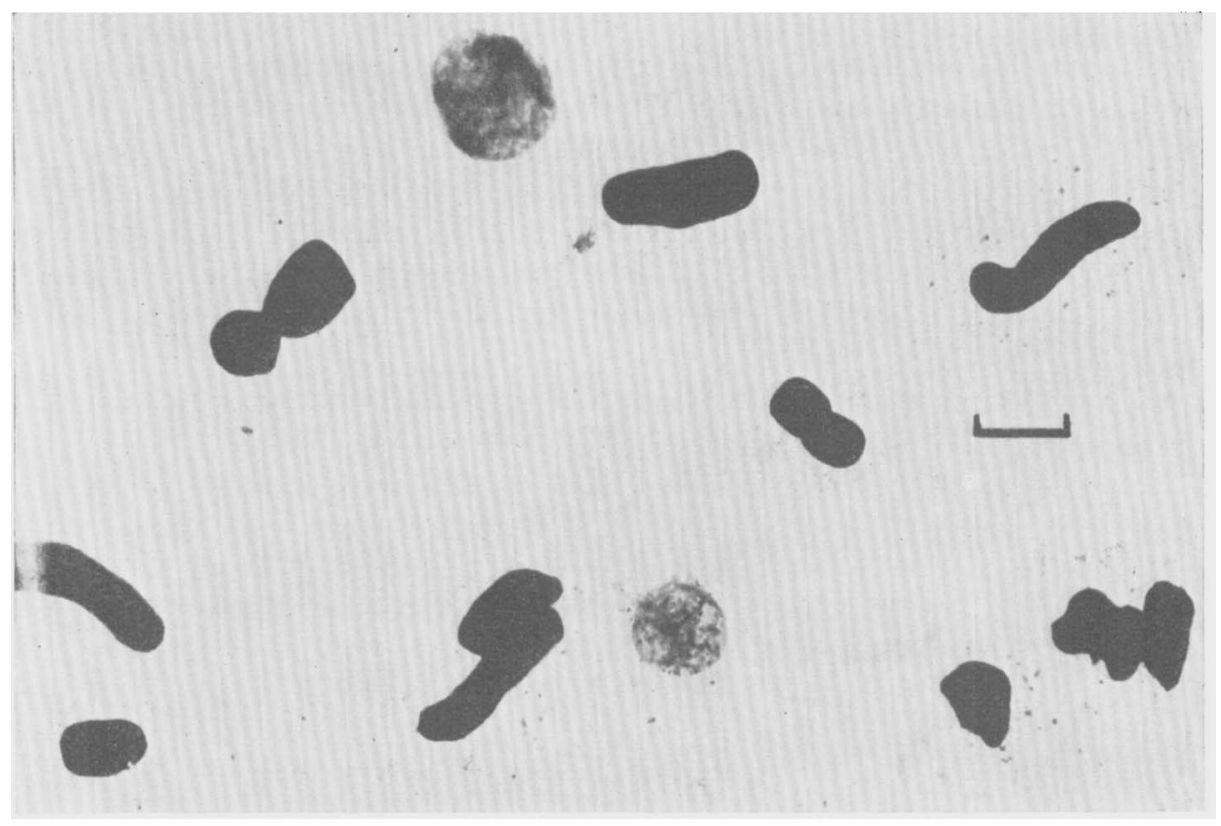

(c)

Fig. I. Electron micrographs of penicillin spheroplasts of Escherichia coli NCTC 86 incubated in the presence and absence of ampicillin. (a) Spheroplasts before incubation (scale marker $=$ $2.0 \mu \mathrm{m}$ ). (b) Spheroplasts after $3 \mathrm{~h}$ incubation in SG broth containing $5 \mu \mathrm{g}$ ampicillin/ml (scale marker $=2 \cdot 0 \mu \mathrm{m}$ ). $(c)$ Spheroplast suspension after $4 \mathrm{~h}$ incubation in SG broth (scale marker $=$ 4.0 $\mu \mathrm{m})$. 
Table I. Effect of varying preparative conditions on the yield of spheroplasts

Treatment

Eschichia coli NCTC 86; conditions of Voss (1964)

Lysozyme decreased to $10 \mu \mathrm{g} / \mathrm{ml}$

EDTA concentration decreased to $0.4 \mathrm{~mm}$

Inoculum decreased to $25 \%$

Spheroplasts stabilized by the addition of $0.02 \mathrm{M}-\mathrm{MgSO}_{4}$

Pre-exposure to tris buffer, i.e. organisms incubated $30 \mathrm{~min}$ at

$37^{\circ} \mathrm{C}$ with tris $(0.033 \mathrm{M})$, washed 3 times with water and finally

treated with EDTA and lysozyme in the absence of tris

Treatment time decreased to 5 min, i.e. organisms treated with

EDTA and lysozyme, suspension centrifuged at $2{ }^{\circ} \mathrm{C}$ and supernatant then removed to terminate the reaction

Phosphate buffer $(0.067 \mathrm{M}, \mathrm{pH} 8.0)$ substituted for tris buffer

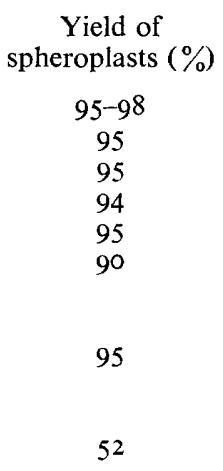

\section{EDTA-lysozyme spheroplasts}

Differential microscopic counts of Escherichia coli NCTC 86 suspensions showed that about $95 \%$ of the organisms were converted into spherical bodies after 5 min treatment with EDTAlysozyme. Osmotic-shocking of the preparations in water produced lysis of all of the spheres as observed microscopically.

A suspension of EDTA-lysozyme spheroplasts was centrifuged and the spheroplasts resuspended in SS medium to half the original volume. The concentrated suspension was used to inoculate fresh SS medium. Control cultures of Escherichia coli NCTC 86 in $0.3 \mathrm{M}$-sucrose were similarly concentrated and the turbidity of both suspensions measured during several hours at $37^{\circ} \mathrm{C}$. A lag period ( 2 to $3 \mathrm{~h}$ ) ensued before the turbidity of the spheroplast suspensions began to increase. Microscopic observations revealed that during this lag period the proportion of rods in the spheroplast suspension gradually increased until, after 4 or $5 \mathrm{~h}$ incubation, rods were predominant. Very few of the spheroplasts increased in size and tests showed that, between $\mathrm{I} \cdot 5$ and $3 \mathrm{~h}$ after inoculation, the cultures ceased to be osmotically fragile.

The rapid increase in turbidity of the spheroplast suspensions following the long lag period was due to the appearance of osmotically stable rods, resulting either from multiplication of the small number of unconverted organisms in the inoculum or reversion of the spheroplasts into normal rods. Total chamber counts and viable counts, using $0.3 \mathrm{M}$-sucrose as diluent and $\mathrm{C}$ agar as a plating medium, showed that only $0.4 \%$ of organisms in spheroplast suspensions could form colonies in agar. Variations in the diluent ( $0.5 \mathrm{M}$-sucrose or SG broth) and in the plating medium (SG agar) did not increase this proportion. A comparison was made of the turbidimetric increase in SS medium at $37^{\circ} \mathrm{C}$ of spheroplast suspensions and a range of Escherichia coli inocula provided by diluting a control suspension with $0.3 \mathrm{M}$ sucrose, centrifuging and resuspending in SS medium. The rate of increase in turbidity from inocula diluted to contain between 2.5 and $5.0 \%$ of the control suspensions was equivalent to that observed for spheroplast suspensions, thus correlating with the proportion of unaltered rods observed in such suspensions. The length of lag periods and the eventual rates of growth in isotonic SS medium of osmotically shocked and non-shocked spheroplast suspensions were also similar. It was concluded that growth of the small number of unconverted rods, rather than the spheroplasts themselves, was responsible for the turbidimetric increase of the spheroplast preparations.

Goldschmidt \& Wyss (1966) observed that suspensions of Azotobacter vinlandii were 
Table 2. Effect of antibacterial agents on the growth of EDTA-treated Escherichia coli NCTC 86

\begin{tabular}{|c|c|c|}
\hline \multirow[b]{2}{*}{ Agent } & \multicolumn{2}{|c|}{$\mathrm{ED}_{50} *(\mu \mathrm{g} / \mathrm{ml})$} \\
\hline & $\begin{array}{l}\text { Untreated } \\
\text { cells }\end{array}$ & $\begin{array}{l}\text { EDTA-treated } \\
\text { cells }\end{array}$ \\
\hline Actinomycin D & $>100$ & $0.2 \dagger$ \\
\hline Bacitracin & 1000 & $506 \cdot 9$ \\
\hline Benzylpenicillin & $3 \cdot 6$ & $3 \cdot 5$ \\
\hline Cephaloridine & $3 \cdot 0$ & $2 \cdot 7$ \\
\hline Cephalosporin PI & $>10000$ & $432 \cdot 5 \dagger$ \\
\hline Cycloserine & $20 \cdot 7$ & $25 \cdot 9$ \\
\hline Dichlorobenzylalcohol & $29 \mathrm{I} \cdot 8$ & $247^{\circ} 0$ \\
\hline Erythromycin & $28 \cdot 2$ & $0.7 \dagger$ \\
\hline Lincomycin & $17 \cdot 3$ & $21 \cdot 0$ \\
\hline Nalidixic acid & $I \cdot 9$ & $\mathrm{I} \cdot 7$ \\
\hline Novobiocin & $101 \cdot 8$ & $23.5 \dagger$ \\
\hline Polymyxin B & 0.9 & 0.6 \\
\hline Quinacillin & I94. I & 187.6 \\
\hline Sodium dodecyl sulphate & $>1000$ & $>1000$ \\
\hline Vancomycin & $246 \cdot I$ & $38 \cdot 3 \dagger$ \\
\hline
\end{tabular}

* Concentration required to produce $50 \%$ inhibition of growth yield after a $4 \mathrm{~h}$ incubation period.

$\dagger$ Statistically significant difference, $P \leqslant 0.05$.

killed by brief exposure to a combination of EDTA and tris buffer but when the organisms were thoroughly washed with water after exposure to tris buffer alone, and then treated with EDTA, a high proportion remained viable. Hirokawa (1966) reported that spheroplasts formed by the growth of Escherichia coli in the presence of benzylpenicillin possess a nutritional defect and only revert to normal bacteria in a complex growth medium. It therefore seemed possible that our EDTA-lysozyme spheroplasts were either killed during preparation or possessed a nutritional defect which was not rectified by SS medium used in the growth experiments. Attempts to improve the yield of spheroplasts from $E$. coli NCTC 86 by modifying the preparative method were unsuccessful (Table I). With E. coli NCTC8007, I 202 and I 203, conversions into spheroplasts of 70,92 and $95 \%$, respectively, were obtained, but with Proteus vulgaris A479, Pseudomonas aeruginosa Ios, Salmonella typhimurium NCTC 57 I0 and Shigella flexneri WB I no conversion occurred. Neither the treatments detailed in Table I, nor the substitution of $\mathrm{C}$ broth for SS growth medium or the addition of $0.2 \% \mathrm{MgSO}_{4}$ to this latter medium, improved the viability of the spheroplasts.

\section{EDTA-treated organisms}

Leive (1965b) reported that a brief treatment of Escherichia coli AB IIO5 with EDTA renders the organisms both permeable and sensitive to actinomycin $\mathrm{D}$. We therefore compared the effect of a number of antibacterial compounds on the growth in nutrient broth of EDTAtreated and untreated $E$. coli NCTC 86 . Table 2 shows that pretreatment with 0.2 mM-EDTA increased the sensitivity of $E$. coli NCTC 86 to actinomycin D and erythromycin, the effect was less with bacitracin, cephalosporin Pr, novobiocin and vancomycin. Activity of the lytic agents, polymyxin B and SDS, and the specific inhibitors of cell-wall synthesis, benzylpenicillin, cephaloridine, cycloserine and quinacillin, was not enhanced by EDTA pretreatment.

Immediately after treatment of Escherichia coli NCTC 86 with 0.2 mM-EDTA alone, the viable count decreased by $27 \%$; 0.1 and 0.05 mM-EDTA produced decreases of 22 and $17 \%$ 


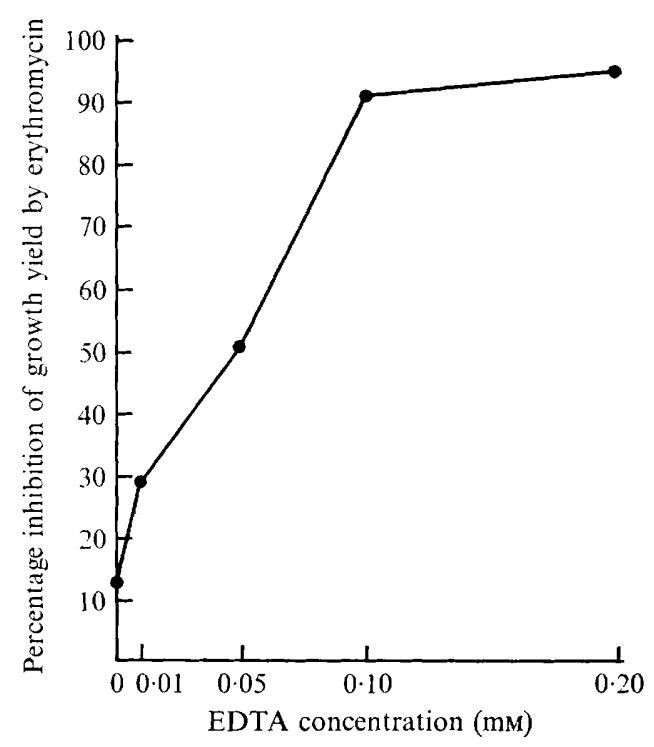

Fig. 2. Effect of EDTA concentration on the potentiation of erythromycin (Io $\mu \mathrm{g} / \mathrm{ml})$.

respectively. Only when the inoculum density was decreased by $99 \%$ did Io $\mu$ g erythromycin/ $\mathrm{ml}$ produce an inhibition of growth rate of a control culture of $E$. coli comparable to the inhibition it produced of E. coli pretreated with 0.2 mM-EDTA. We concluded that the potentiation of erythromycin activity by EDTA was not due to a simple addition of inhibitory activities.

Factors affecting the EDTA-mediated potentiation of erythromycin against Escherichia coli $\mathrm{NCTC} 86$

Growth of EDTA-treated and control organisms, both in the presence and the absence of Io $\mu \mathrm{g}$ erythromycin $/ \mathrm{ml}$, was followed turbidimetrically. Fig. 2 shows the effect of various EDTA concentrations on the subsequent activity of erythromycin; potentiation was maximal at an EDTA concentration of $0.1 \mathrm{mM}$, whilst a concentration of $0.01 \mathrm{mM}$ caused some effect. This potentiation was completely abolished by the presence of magnesium sulphate $(0.5 \%, \mathrm{w} / \mathrm{v})$ or of nutrient broth, presumably containing many different metal cations, during the EDTA treatment.

Treatment of suspensions with EDTA at 4, Io, 23 and $37^{\circ} \mathrm{C}$ led to similar degrees of enhancement of erythromycin activity.

The changes produced by EDTA treatment were reversible. If treated Escherichia coli were incubated in nutrient broth for less than $15 \mathrm{~min}$ before addition of erythromycin, a decrease in potentiation resulted, and after 60 min incubation potentiation was practically eliminated.

\section{Effect of EDTA on cellular morphology}

Electron microscopy of EDTA-treated Escherichia coli NCTC 86 and a control obtained by diluting suspensions with nutrient broth to inactivate the chelating agent, revealed that most of the organisms in suspensions treated with 0.2 mM-EDTA (Fig. $3 b$ ) were considerably swollen when compared with untreated organisms (Fig. $3 a$ ) and their surfaces appeared to be covered by globules (Fig. $3 b$ ). Similar detached globules were also visible. Globule forma- 


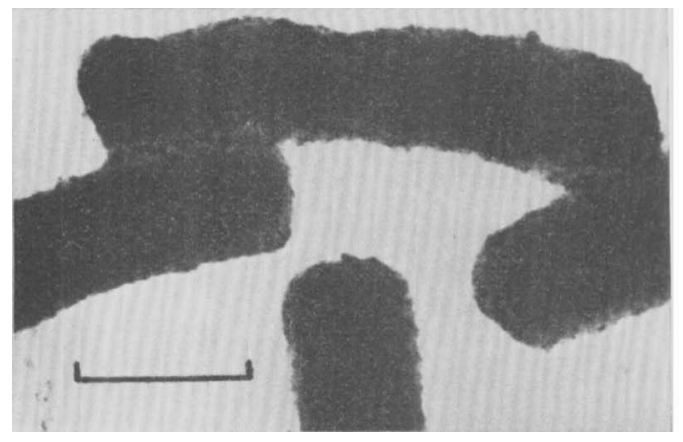

(a)

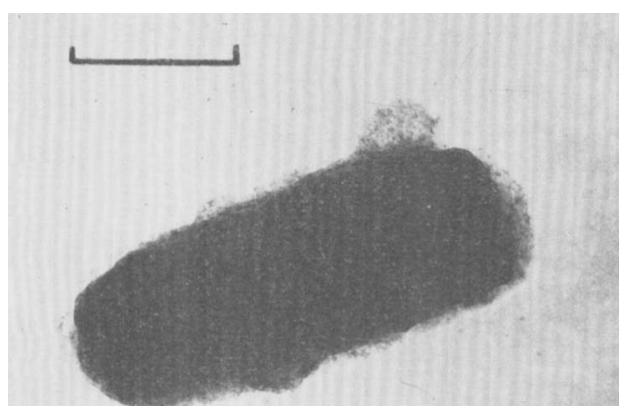

(c)

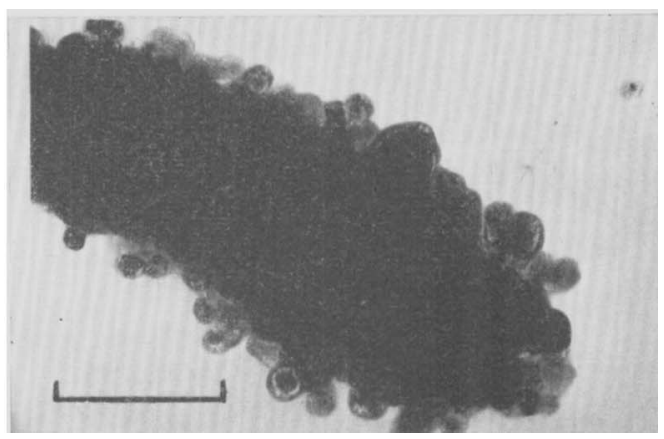

(b)

Fig. 3. Electron micrographs showing the effect of EDTA on Escherichia coli NCTC 86. (a) Untreated organisms (scale narker $=0.5 \mu \mathrm{m}$ ). $(b)$ and (c) EDTA-treated organisms (scale marker = $0.5 \mu \mathrm{m})$.

\section{Table 3. Effect of treatment with different chelating agents on the} erythromycin-sensitivity of Escherichia coli NCTC 86

E. coli was treated with the chelating agent ( $(0.1 \mathrm{~mm})$ under the usual conditions, incubated in nutrient broth at $37^{\circ} \mathrm{C}$, both in the presence and absence of a range of concentrations of erythromycin, and the growth followed turbidimetrically.

\section{Chelator}

None

Ethylenediamine tetraacetic acid

Cyclohexane-1,2-diamine tetraacetic acid

Diethylene triamine pentaacetic acid

Nitrilo triacetic acid

Bis hydroxyphenyl ethylenediamine diacetic acid

Glycine

Histidine

Cysteine

Ethylenediamine

Oxalic acid

DL-Penicillamine

I-Hydroxyethane I, I-diphosphoric acid

$N-N$-di(2-Hydroxyethyl) glycine

\section{Stability}

$\mathrm{ED}_{50} *$ for erythromycin constant for complex with $\mathrm{Mg}^{2+}+$ General chelating activity $\uparrow$

* Concentration $(\mu \mathrm{g} / \mathrm{ml})$ required to produce $50 \%$ inhibition of growth yield after $4 \mathrm{~h}$ incubation. + See Albert (1968) and West (1969).

+++ , High activity; ++ , moderate activity; + , low activity; n.a., data not available. 


\section{Table 4. Effect of erythromycin on EDTA-treated bacteria}

The cultures were pretreated with 0.2 mM-EDTA, incubated at $37^{\circ} \mathrm{C}$ in nutrient broth containing $10 \mu \mathrm{g}$ erythromycin $/ \mathrm{ml}$ and the percentage inhibition of growth yield determined after $4 \mathrm{~h}$ incubation $(2.5 \mathrm{~h}$ for Aerobacter aerogenes).

\begin{tabular}{|c|c|c|c|}
\hline \multirow[b]{2}{*}{ Organism } & \multirow[b]{2}{*}{ Strain } & \multicolumn{2}{|c|}{ Inhibition of growth $(\%)$} \\
\hline & & $\begin{array}{l}\text { Untreated } \\
\text { organisms }\end{array}$ & $\begin{array}{c}\text { EDTA-treated } \\
\text { organisms }\end{array}$ \\
\hline \multirow[t]{14}{*}{ Escherichia coli } & NCTC 86 & 2 & 9I \\
\hline & NCTC 8007 & 15 & 81 \\
\hline & PHL 4 & 6 & 48 \\
\hline & PHL 6 & Io & 56 \\
\hline & PHL 20 & 0 & 46 \\
\hline & PHL 2 I & I 2 & 55 \\
\hline & PHL 34 & 2 & 49 \\
\hline & PHL 37 & 0 & $3 I$ \\
\hline & PHL 42 & 5 & 44 \\
\hline & PHL 44 & 5 & 60 \\
\hline & PHL 46 & 10 & 56 \\
\hline & PHL 54 & 4 & 94 \\
\hline & PHL 56 & 18 & 70 \\
\hline & PHL 6o & II & 54 \\
\hline Aerobacter aerogenes & NCTC 8172 & $30^{*}$ & $67^{*}$ \\
\hline Proteus mirabilis & NCTC 5887 & 13 & $5 I$ \\
\hline Salmonella paratyphi в & NCTC 5704 & 9 & 64 \\
\hline
\end{tabular}

tion was variable and in some preparations treated organisms, although considerably swollen, were found to possess only an occasional protrusion (Fig. $3 \mathrm{c}$ ). Organisms treated with $0 \cdot 1$ mM-EDTA were not strikingly different in appearance from untreated cells but some were swollen and a very few bore a solitary protrusion.

\section{Activity of other chelating agents and some EDTA amides}

Only chelating agents with a polyacetic acid structure potentiated the effect of erythromycin on Escherichia coli NCTC86 (Table 3). There was some correlation of potentiating activity and chelating ability; compounds with four or five acetic acid moieties were more active than those containing only two or three.

When tested under the same conditions none of the amides of EDTA potentiated as effectively as EDTA itself. Those derived from glycine or DL-methionine were the most active. Although pretreatment of Escherichia coli NCTC86 with these derivatives did not inhibit subsequent growth, all the amides inhibited growth in nutrient broth when added directly to the medium at a concentration of $2.0 \mathrm{mM}$ (about $1000 \mu \mathrm{g} / \mathrm{ml}$ ), unlike EDTA itself.

Erythromycin sensitivity of EDTA-treated Escherichia coli in vivo

Subcutaneous administration of $200 \mathrm{mg}$ erythromycin/ $\mathrm{kg}$ did not significantly affect the M.S.T. of mice infected intraperitoneally with Escherichia coli NCTC 86, but when the infecting bacteria were pretreated with EDTA, which did not appear to affect the virulence of the organism, erythromycin treatment extended the M.S.T. to 5.8 days, compared with a M.S.T. of 0.6 days for untreated control mice.

Single intraperitoneal doses of individual amides of EDTA at a level of $400 \mathrm{mg} / \mathrm{kg}$ were tolerated by normal mice although EDTA at this dose level was lethal. When administered 
orally at a dose of $400 \mathrm{mg} / \mathrm{kg}$, together with erythromycin $(200 \mathrm{mg} / \mathrm{kg})$, to mice infected with Escherichia coli $\mathrm{NCTC} 86$, the amides derived from D-alanine or DL-methionine gave a slight (10\%), but significant $(P=0.05)$ increase in M.S.T. Neither EDTA nor any of these derivatives protected the animals against the infection in the absence of erythromycin.

All of 17 strains, representing four Gram-negative genera, were rendered markedly more sensitive to erythromycin by EDTA-treatment but the degree of erythromycin potentiation varied considerably between strains of Escherichia coli (Table 4).

\section{DISCUSSION}

Growing protoplasts can provide a useful system for investigating the mode of action of antibacterial compounds, but it is difficult to obtain suitable forms from Escherichia coli. Penicillin treatment yields spheroplast suspensions contaminated with a small residual proportion of viable rods and the spheroplasts themselves revert fairly quickly in the absence of penicillin. These contaminating rods obscure spheroplast growth unless a cell-wall inhibitor is added. Hugo \& Russell (I960) have drawn attention to the puzzling phenomenon of surviving rods which, although not converted to spheroplasts by penicillin treatment, are genetically sensitive to the antibiotic. The treatment with EDTA which renders $E$. coli susceptible to lysozyme is apparently lethal to the bacteria through an unknown mechanism (Goldschmidt \& Wyss, 1967; Neu, I969; Voss, 1967) and we were unable to obtain growth of spheroplasts produced in this way. However, treatment with low concentrations of EDTA alone for brief periods, first described by Leive ( $1965 b$ ), apparently alters permeability without impairing the growth of $E$. coli significantly, and allows a study of the activity of bacteriostatic agents.

We have found that compounds which are considered to inhibit mucopeptide synthesis specifically are far less active against penicillin spheroplasts than against the parent Escherichia coli cells. As the spheroplasts are devoid of mucopeptide this is not surprising, but the failure in our experiments of EDTA-treatment to enhance sensitivity to agents of this type was unexpected. Subinhibitory concentrations of EDTA have been reported to reduce the M.I.C. of some penicillins and other agents in tube dilution experiments using strains of E. coli, Pseudomonas aeruginosa and Proteus mirabilis (Weiser, Asscher \& Wimpenny, 1968). However, EDTA was present throughout the growth period in the latter determinations and may have exerted several effects on the penicillin-resistant strains of $E$. coli employed, including interference with penicillinase production. Our results are therefore not necessarily contradictory as we removed the chelating agent before measuring the activity of the inhibitors. A similar brief treatment of Salmonella typhi 090 I with EDTA has been reported to cause very little increase in sensitivity to penicillin in that organism, although sensitivity to actinomycin was increased markedly (Muschel \& Gustafson, 1968). HamiltonMiller (I966) found that penicillin penetration to intracellular penicillinase in E. coli 419 cells was facilitated by treatment with EDTA (0. I to $10.0 \mathrm{~mm}$ ). Apart from differences in organisms and experimental conditions this apparent anomaly may be explained if the locations within $E$. coli of intracellular penicillinase and the sensitive mucopeptide-synthesising site are different. Possibly penicillinase is situated more superficially and, hence, is more readily unmasked by EDTA.

Bacitracin, novobiocin and vancomycin, which are believed to act both on cell-wall synthesis and at other loci (Reynolds, I966), were only slightly potentiated by EDTA treatment. This finding is also consistent with EDTA treatment diminishing the barrier of penetration to only one of several sites of action. 
SDS and TCS were more effective in lysing penicillin spheroplasts than rods. This suggests that the presence of mucopeptide antagonizes the activity of these agents. Using ${ }^{14} \mathrm{C}$-labelled TCS, Hamilton (I968) found that the cell wall of Escherichia coli retarded absorption of TCS on to the cytoplasmic membrane. EDTA-lysozyme treatment enhances the activity of polymyxin B, another agent which impairs membrane function, but in our experiments neither penicillin nor EDTA-treatment alone was effective in this way. Thus both mucopeptide and the outer layers of the cell wall retard penetration of polymyxin, or support the cytoplasmic membrane against damage by the compound, in E. coli.

None of the other agents examined was highly active against penicillin spheroplasts; in contrast, actinomycin D and erythromycin were markedly potentiated by EDTA treatment. These antibiotics act on RNA and protein synthesis respectively at sites beneath the cell wall (Reich, I966; Vazquez, I966). Mao \& Putterman (I968) have shown that Gram-positive bacteria accumulate 100-fold more erythromycin than Gram-negative organisms although cell-free protein synthesizing preparations from both Escherichia coli and Staphylococcus aureus are quickly susceptible to erythromycin. Thus the insensitivity of $E$. coli to this antibiotic, as to actinomycin $\mathrm{D}$, appears to be due to poor penetration to the susceptible site.

The conditions necessary for EDTA-treatment to render Escherichia coli sensitive to erythromycin are similar to those described by Leive $(1965 b, 1968)$ for the potentiation of actinomycin $\mathrm{D}$, although the two antibiotics are chemically quite distinct. Leive (1965c) showed by chemical means that EDTA-treatment under these conditions depletes the lipopolysaccharide of $E$. coli. We have observed by electron microscopy that treated rods appear to lose material from their surfaces. This phenomenon is similar to that in a lysine-requiring mutant of E. coli during lysine-limited growth found by Work, Knox \& Vesk (I966) who showed that these bacteria were losing a lipopolysaccharide-lipoprotein complex from their cell walls. Lipopolysaccharide does not occur in Gram-positive bacteria (Glauert \& Thornley, 1969) and its presence in Gram-negative bacteria may explain the selectivity of many antibacterials. Compounds which inhibit Gram-positive bacteria may therefore be capable of inhibiting $E$. coli, and perhaps other bacteria with complex walls, if they could reach the site of the susceptible metabolic process.

The exact mechanism by which EDTA enhances the susceptibility of Gram-negative bacteria to inhibitory compounds remains to be elucidated but we think that the primary effect is at the site of insertion of lipopolysaccharide into the outer membrane of the wall (Schnaitman, 1971). Chelation is probably involved, but it seems that there is some specificity in chemical structure since chelating agents unrelated to EDTA lack effect. The enhanced susceptibility of Escherichia coli to erythromycin appears to be retained in vivo, at least under the experimental conditions that we have used. This raises the question of the design of chelating agents which could react specifically with infecting Gram-negative bacteria and render them susceptible to narrow-spectrum antibiotics without adverse effect on the host. If chelating groups could be unmasked by the target organism specificity may be achieved but the EDTA derivatives that we have examined did not show potential chemotherapeutic utility in our in vivo experiments, although they appeared less toxic to the mouse than EDTA itself.

We are indebted to Mr G. M. Fisher for his expert technical assistance throughout this work and to Mr L. P. S. Piper for his skilful aid with the electron microscopy. 


\section{REFERENCES}

Albert, A. (1968). Stability constants of some complexing agents. In Selective Toxicity, p. 3I8. London: Methuen.

Gauze, G. G., Loshraseva, N. P. \& YU, V. D. (1965). Mechanism of oligomycin action. Federal Proceedings Translation Supplement 25, T. 329-T. 332.

GiLbY, A. R. \& FEw, A. V. (1960a). Lysis of protoplasts of Micrococcus lysodeikticus by ionic detergents. Journal of General Microbiology 23, 19-26.

Gilby, A. R. \& FEw, A. V. (I960 b). Lysis of protoplasts of Micrococcus lysodeikticus by alcohol. Journal of General Microbiology 23, 27-33.

Glauert, A. M. \& Thornley, M. J. (I 966). Glutaraldehyde fixation of Gram-negative bacteria. Journal of the Royal Microscopical Society 85, 449-453.

Glauert, A. M. \& Thornley, M. J. (1969). Topography of the bacterial cell wall. Annual Review of Microbiology 23, 159-198.

Goldschmidt, M. C. \& Wyss, O. (I966). Chelation effects on Azotobacter cells and cysts. Journal of Bacteriology 9r, I 20-I 24 .

Goldschmid, M. C. \& Wyss, O. (1967). The role of tris in EDTA toxicity and lysozyme lysis. Journal of General Microbiology 47, 421-43I.

Hamilton, W. A. (1968). The mechanism of the bacteriostatic action of tetrachlorosalicylanilide: a membraneactive antibacterial compound. Journal of General Microbiology 50, 44I-458.

Hamilton-Miller, J. M. T. (I966). Damaging effects of EDTA and penicillins on permeability barriers in Gram-negative bacteria. Biochemical Journal roo, 675-682.

HANCOCK, R. \& Fitz-JAmes, P. C. (I964). Some differences in the action of penicillin, bacitracin and vancomycin on Bacillus megaterium. Journal of Bacteriology 87, 1044-1050.

HAYwood, A. M. \& Sinshermer, R. L. (1963). Inhibition of protein synthesis in Escherichia coli protoplasts by actinomycin D. Journal of Molecular Biology 6, 247-249.

Hirokawa, H. (1962). Biochemical and cytological observations during the reversing process from spheroplasts to rod form cells in Escherichia coli. Journal of Bacteriology 84, I I 6I-I I 68 .

Hirokawa, H. (I966). Properties of rod cells reversed from penicillin spheroplasts in Escherichia coli. Journal of Bacteriology 9r, I25-1 28.

Hugo, W. B. \& Russell, A. D. (1960). Quantitative aspects of penicillin action on Escherichia coli in hypertonic media. Journal of Bacteriology 8o, 436-440.

KAY, D. \& FILDES, P. (1950). The calcium requirement of a typhoid bacteriophage. British Journal of Experimental Pathology 31, 338-348.

LEIVE, L. (I965a). Actinomycin sensitivity in Escherichia coli produced by EDTA. Biochemical and Biophysical Research Communications 18, $13-17$.

LEIVE, L. (I965b). A non-specific increase in permeability in Escherichia coli produced by EDTA. Proceedings of the National Academy of Sciences of the United States of America 53, 745-750.

LEIVE, L. (1965c). Release of lipopolysaccharide by EDTA treatment of Escherichia coli. Biochemical and Biophysical Research Communications 21, 290-296.

LEIVE, L. (1968). Studies on the permeability change produced in coliform bacteria by EDTA. Journal of Biological Chemistry 243, 2373-2380.

LitChField, J. T. (I949). A method for rapid graphic solution of time per cent effect curves. Journal o, Pharmacology and Experimental Therapeutics 97, 399-408.

Loveless, L. E., Spoerl, E. \& Weisman, T. H. ( 1954). A survey of effects of chemicals on division and growth of yeast and Escherichia coli. Journal of Bacteriology 68, 637-644.

MACH, B. \& TATUM, E. L. (I963). Ribonucleic acid synthesis in protoplasts of Escherichia coli. Inhibition by actinomycin D. Science, New York 139, I05I-I052.

Mao, J. C.-H., \& Putterman, M. (1968). Accumulation in Gram-positive and Gram-negative bacteria as a mechanism of resistance to erythromycin. Journal of Bacteriology 95, I I I I-I I I 7 .

Muschel, L. H. \& Gustáfson, L. (I968). Antibiotic, detergent, and complement sensitivity of Salmonella typhi after ethylene-diamine tetraacetic acid treatment. Journal of Bacteriology 95, 20I0-20I 3.

NEU, H. C. (1969). The role of amine buffers in EDTA toxicity and their effect on osmotic shock. Journal of General Microbiology 57, 21 5-220.

RaZIN, S. \& Argaman, M. (1963). Lysis of Mycoplasma, bacterial protoplasts, spheroplasts and L-forms by various agents. Journal of General Microbiology 30, I 55-172. 
REICH, E. (1966). Binding to DNA and inhibition of DNA functions by actinomycins. In Biochemical Studies of Antimicrobial Drugs. XVIth Symposium of the Society for General Microbiology, pp. 266-280. Cambridge University Press.

Reynolds, P. E. (1966). Antibiotics affecting cell-wall synthesis. Biochemical Studies of Antimicrobial Drugs. $X V I t h$ Symposium of the Society for General Microbiology, pp. 47-69.

Schnaitman, C. A. (197I). The effect of ethylene-diaminetetraacetic acid, Triton X-I00, and lysozyme on the morphology and chemical composition of isolated cell walls of Escherichia coli. Journal of Bacteriology I08, 553-563.

Shockman, G. D. \& Lampen, J. O. (1962). Inhibition by antibiotics of the growth of bacterial and yeast protoplasts. Journal of Bacteriology 84, 508-51 2.

VAZQUEZ, D. (1966). Mode of action of chloramphenicol and related antibiotics. In Biochemical Studies of Antimicrobial Drugs. XVIth Symposium of the Society for General Microbiology, pp. I 69-191. Cambridge University Press.

Voss, J. G. (I964). Lysozyme lysis of Gram-negative bacteria without production of spheroplasts. Journal of General Microbiology 35, 313-317.

Voss, J. G. (1967). Effect of organic cations on the Gram-negative cell wall and their bactericidal activity with EDTA and surface-active agents. Journal of General Microbiology 48, 39I-400.

WeISER, R., AsSCHER, A. W. \& WIMPENNY, J. (1968). In vitro reversal of antibiotic resistance by ethylenediamine tetraacetic acid. Nature, London 219, I 365-I 366.

WEST, T. S. (1969). Complexometry with EDTA and Related Reagents, p. 223. B.D.H. Chemicals Ltd.

WORK, E., KNOX, K. W. \& VesK, M. (1966). The chemistry and electron microscopy of an extracellular lipopolysaccharide from Escherichia coli. Annals of the New York Academy of Sciences 133, 438-449.

YUDKIN, M. D. (1963). The effect of penicillin, novobiocin, streptomycin and vancomycin on membrane synthesis by protoplasts of Bacillus megaterium. Biochemical Journal 89, 290-296. 